
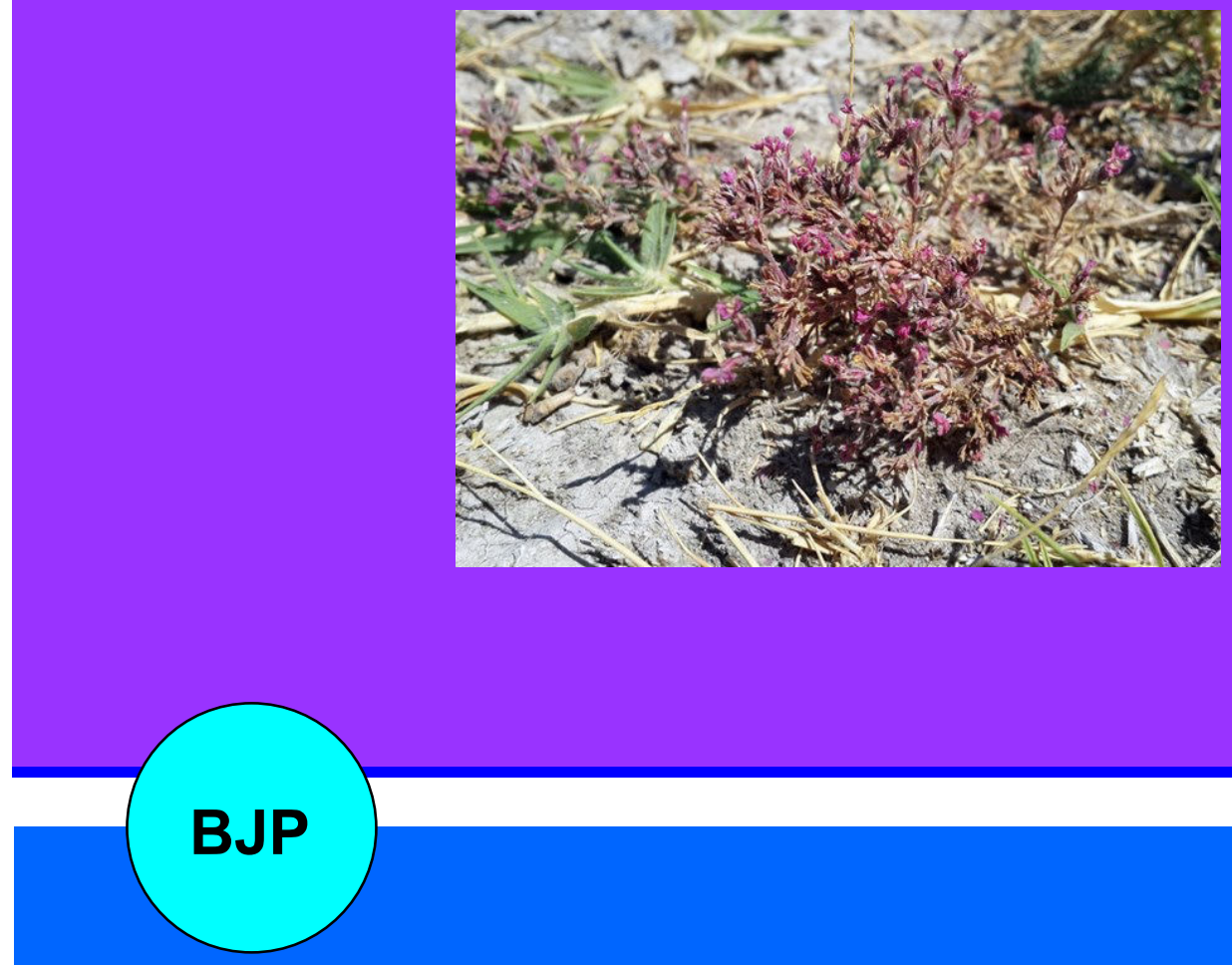

Bangladesh Journal of Pharmacology

Research Article

Determination of the chemical composition and antimicrobial activity of Frankenia hirsuta 


\title{
Determination of the chemical composition and antimicrobial activity of Frankenia hirsuta
}

\author{
Kerem Canli', Özcan Şimşek², Ali Yetgin3, and Ergin Murat Altuner4 \\ ${ }^{1}$ Department of Biology, Faculty of Science, Dokuz Eylül University, Izmir, Turkey; ${ }^{2}$ Department of Biology, Faculty \\ of Science, Ankara University, Ankara, Turkey; ${ }^{3}$ Department of Biotechnology, Institute of Engineering and Science, \\ Izmir Institute of Technology, Izmir, Turkey; ${ }^{4}$ Department of Biology, Faculty of Science and Arts, Kastamonu \\ University, Kastamonu, Turkey.
}

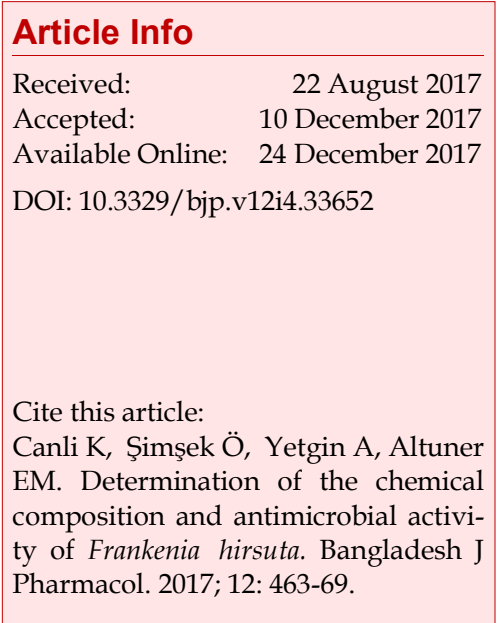

\begin{abstract}
Frankenia hirsuta is widely located in Turkey, but the antimicrobial potential and biochemical composition analysis of it weren't determined yet. By using the disk diffusion method, the susceptibility of 17 bacteria and 1 fungi were analyzed, which included Bacillus, Candida, Enterobacter, Enterococcus, Escherichia, Klebsiella, Listeria, Pseudomonas, Salmonella and Staphylococcus genera. $0.8,1.5$ and $3.1 \mathrm{mg}$ of samples were prepared by using absolute ethanol. The bioactive composition of the plant extract was determined by gas chromatography-mass spectroscopy, and National Institute of Standards and Technology library was used for the mass spectra analysis. The results showed that $F$. hirsuta had antimicrobial activity against all of the studied micro-organisms except E. aerogenes and E. coli. Several active metabolites were identified, but some composition of this sample didn't match with the library. These results are the first report for the antimicrobial potential and biochemical composition of F. hirsuta.
\end{abstract}

\section{Introduction}

Foodborne pathogens cause critical problems all over the world. They don't just cause dangerous illnesses, but cause food spoilages, which is main problem in the food production and storage. Food source microbiological quality is an important topic for human health and the main reason for food contamination is foodborne pathogens. There are 15 major foodborne pathogens, which cause annually 76 million illness and 5,000 death in US. The most common are Listeria monocytogenes, Escherichia coli, Klebsiella pneumoniae, Staphylococcus aureus, Salmonella and Candida spp., which exist in various types of foods (Mead et al., 1999). According to US report in 2010, only E. coli and Salmonella spp. cause 1.4 million foodborne illnesses and responsible for a $\$ 2.7$ billion loss (USDA, 2010).
Discovery of new drugs/agents has critical importance, thus the investigation of antimicrobial potentials of aromatic plants and the analysis of their biochemical composition are required. They have the potential to synthesize different antimicrobial compounds, therefore scientific research became a popular trend to determine their unknown biochemical composition and their activity (Daglia, 2011).

Frankenia genus are salt tolerant aromatic plants and related research is limited (Hamzaoglu and Akson, 2009). Frankenia hirsuta belongs to Frankeniaceae family and it is widely distributed in Turkey (Vural et al., 2014). Its antiphage (Delitheos et al, 1997) and antischistosomal (Yousif et al., 2007) activities were identified before, however antimicrobial activity and its biochemical composition weren't analyzed yet. 
The main purpose of this study was to investigate antimicrobial activity of $F$. hirsuta against 18 microorganisms and determining its biochemical composition.

\section{Materials and Methods}

\section{Plant samples}

F. hirsuta is an aromatic halophytic plant in Turkey. Samples collected from salty soil ground of Aksaray.

\section{Extraction procedure}

F. hirsuta samples were dried under shade and they were ground into fine powder by a grinder. These samples were shaken in absolute ethanol (SigmaAldrich) at $125 \mathrm{rpm}$ for 2 days at room temperature (Canli et al., 2016a). After that, all of them were filtrated through Whatman No. 1 filter paper into evaporation flasks. Filtrates were evaporated by a rotary evaporator (Buchi R3) at $45^{\circ} \mathrm{C}$ (Altuner et al., 2012). Finally, remnants were collected and they are used to prepare as $0.8,1.5$ and $3.1 \mathrm{mg} / \mathrm{mL}$ stocks.

\section{Microorganisms}

A broad range of Gram positive bacteria, Gram negative bacteria and yeast were chosen to analyze the antimicrobial effect of F. hirsuta. For this reason, 17 bacteria and 1 fungi species were used and these microorganisms were sustained on nutrient agar (BD Difco, USA). There were 11 bacteria and 1 fungus. Five Gram positive bacteria were Bacillus subtilis DSMZ 1971, Enterecoccus faecalis ATCC 29212, Listeria monocytogenes ATCC 7644, Staphylococcus aureus ATCC 25923 and Staphylococcus epidermidis DSMZ 20044. The Gram negative bacteria were Enterobacter aerogenes ATCC 13048, Escherichia coli ATCC 25922, Pseudomonas aeruginosa DSMZ 50071, Pseudomonas fluorescens P1, Salmonella enteritidis ATCC 13075 and Salmonella typhimurium SL1344. The fungus was Candida albicans DSMZ 1386. Besides, there were 6 non-standard bacteria, which were isolated from the food at Ankara University, Department of Biology, Microbiology Laboratory. Three of them are Gram positive bacteria, which were Enterococcus durans, Enterecoccus faecium and Listeria innocua. The others are Gram negative bacteria, which were Klebsiella pneumoniae, Salmonella infantis and Salmonella kentucky.

\section{Preparation of inocula}

All bacterial strain were incubated at $37^{\circ} \mathrm{C}$ for 24 hours, however Candida albicans DSMZ 1386 was incubated at $27^{\circ} \mathrm{C}$ for 48 hours (Canli et al., 2017a). Each bacteria and yeast were inoculated into $0.9 \%$ sterile saline solution and adjusted to $0.5 \mathrm{McFarland}$ standard, in order to standardize the inocula to contain about $10^{8} \mathrm{cfu} / \mathrm{mL}$ for bacteria and $10^{7} \mathrm{cfu} / \mathrm{mL}$ for Candida albicans (Canli et al., 2015).

\section{Antimicrobial activity test}

The antimicrobial activity F. hirsuta of ethanol extract was performed by disk diffusion test, as described by Altuner et al. (2013). Firstly, Mueller Hinton agar (BD Difco, USA) was poured into $90 \mathrm{~mm}$ sterile petri dish in order to reach a meant depth of $4.0 \pm 0.5 \mathrm{~mm}$. 20, 40 and $80 \mu \mathrm{L}$ of extracts were loaded on $6 \mathrm{~mm}$ oxoid antimicrobial susceptibility test disks. Disks were left to dry overnight at $30^{\circ} \mathrm{C}$ in sterile conditions in order to prevent any remaining of solvent, which may interfere with the results. After that, prepared microorganisms, which were inoculated into the saline solution were streaked on the surface of the petri dishes. These plates were left to dry for $5 \mathrm{~min}$ at room temperature in aseptic conditions. Next, disks were tightly applied to the surface of plates. Finally, these plates were incubated and the inhibition zone diameters were observed (Canli et al., 2016b; 2016c).

\section{Gas chromatography-mass spectrophotometry method (GC-MS)}

For the identification of chemical components, each sample was analyzed by Agilent GC 6890N-Agilent MS 5973 equipped with HP5-MS capillary column (30 m* $0.25 \mathrm{~mm}$; coating thickness $0.25 \mu \mathrm{m}$ ). Analytical conditions were an injector temperature of $350^{\circ} \mathrm{C}$; carrier gas helium at $1 \mathrm{~mL} / \mathrm{min}$; injection mode: split, split ratio 10:1; volume injected: $1 \mu \mathrm{L}$ of sample in ethanol extract and oven temperature programed from 40 to $350^{\circ} \mathrm{C}$ at $4^{\circ} \mathrm{C} / \mathrm{min}$, pressure: $48.2 \mathrm{kPa}$, split flow: $9.9 \mathrm{~mL} / \mathrm{min}$. The MS scan conditions were a transfer line temperature of $280^{\circ} \mathrm{C}$, an interface temperature of $280^{\circ} \mathrm{C}$, and an ion source temperature of $230^{\circ} \mathrm{C}$. Identification of the components was conducted by matching the retention times against National Institute of Standards and Technology (NIST Mass Spectrometry DATA CENTER) data library and crosscheck was applied with previously published data (Canli et al., 2017b).

\section{Controls}

Empty sterile disks and extraction solvent (ethanol) were used as negative controls.

\section{Statistics}

The statistical analysis was executed using a parametric method, the one-way analysis of variance (ANOVA), with a significance level of 0.05 (Chambers and Hastie, 1992). In order to put forward any correlation between the concentration and antimicrobial activity Pearson correlation coefficient was calculated (Becker et al., 1992). All statistical analysis were conducted by using $R$ Studio, version 3.3.2 (Team, 2016). 
Table I

Disk diffusion test result for F. hirsuta

\begin{tabular}{|lccc|}
\hline & \multicolumn{3}{c|}{ Inhibition zone (mm) } \\
\hline & $20 \mu \mathrm{L}$ & $40 \mu \mathrm{L}$ & $80 \mu \mathrm{L}$ \\
\hline B. subtilis & $8 \pm 0.0$ & $9 \pm 1$ & $10 \pm 0.0$ \\
C. albicans & - & $8 \pm 0.0$ & $12 \pm 0.0$ \\
E. aerogenes & - & - & - \\
E. coli & - & - & - \\
E. durans & - & $9 \pm 1$ & $10 \pm 0.0$ \\
E. faecalis & - & $8 \pm 0.0$ & $10 \pm 0.0$ \\
E. faecium & $8 \pm 0.0$ & $14 \pm 1$ & $16 \pm 0.0$ \\
K. pneumoniae & - & - & $7 \pm 0.0$ \\
L. innocula & - & $7 \pm 0.0$ & $8 \pm 0.0$ \\
L. monocyto- & - & $8 \pm 1$ & $10 \pm 0.0$ \\
genes & & & \\
P. aeruginosa & $8 \pm 0.0$ & $8 \pm 0.0$ & $9 \pm 1$ \\
P. fluorescens & $8 \pm 1$ & $9 \pm 0.0$ & $11 \pm 0.0$ \\
S. aureus & $8 \pm 0.0$ & $10 \pm 0.0$ & $12 \pm 0.0$ \\
S. enteritidis & $8 \pm 0.0$ & $19 \pm 1$ & $14 \pm 0.0$ \\
S. epidermidis & $11 \pm 0.0$ & $14 \pm 0.0$ & $16 \pm 0.0$ \\
S. infantis & - & $8 \pm 0.0$ & $10 \pm 0.0$ \\
S. kentucky & $10 \pm 0.0$ & $12 \pm 0.0$ & $14 \pm 0.0$ \\
S. typhimurium & $9 \pm 0.0$ & $10 \pm 0.0$ & $12 \pm 0.0$ \\
“-": No inhibition & & & \\
\hline
\end{tabular}

\section{Results}

Antimicrobial activity of the F. hirsuta ethanol extracts were analyzed. In order to load extracts, the empty sterile disks were used. Then these disks were applied on a Mueller Hinton agar (culture medium), which was inoculated with the micro-organisms. Inhibition zone was observed, when the extracts had activity against these micro-organisms. The diameter of these zones were measured as diameters in $\mathrm{mm}$ as given in Table I. No activities were observed for empty sterile disks and ethanol loaded disks, which are negative controls. Furthermore, the statistical analysis proved that there were no significant difference between the activities of three parallels of each extract volumes, which were 20, 40 and $80 \mu \mathrm{L}$, with $\mathrm{p}$ values of $0.9973,0.9706$ and 0.9972 respectively. On the other hand, the difference between the activities of three extract volumes were observed to be statistically significant with a $p$ value of 0.0017 . In addition, a weak positive correlation was observed between increasing the extract volume tested and the activity observed, where the Pearson correlation coefficient was 0.4273 .

F. hirsuta showed antimicrobial activity against all of the studied micro-organisms except E. aerogenes and E. coli. Two of them had high susceptibility (higher than $15 \mathrm{~mm}$ ). Eleven of them had moderate susceptibility (14 $-10 \mathrm{~mm}$ ) and only three of them had low susceptibility (9-7 mm).

According to Table II, oleic acid (26.3\%), $\mathrm{y}$-sitosterol $(12.9 \%)$, vitamin $\mathrm{E}(11.5 \%), n$-hexadecanoic acid $(9.6 \%)$, benzene,1,3,5-trimethyl- (7.0\%), 9,12-octadecadienoic acid $(Z, Z)-(6.5 \%)$ were mainly found in the composition of F. hirsuta ethanol extract.

\section{Discussion}

F. hirsuta was analyzed against S. enteritidis, S. infantis, S. kentucky, S. typhimurium, and a moderate activity was observed. Salmonella genus is a group of Gram negative bacteria and the species belong to this genus are important foodborne pathogens. Gram negative bacteria have more resistance against aromatic plants than Gram positive bacteria (Canli et al, 2016b). F. hirsuta has antimicrobial activity against all studied Gram positive bacteria and some Gram negative bacteria has resistance against this aromatic plant extract. This result demonstrate that F. hirsuta can be used for large range of microbial infection treatment.

The highest activity was reached against $S$. epidermidis and E. faecium (16 $\mathrm{mm}$ at $3.1 \mathrm{mg})$. Staphylococcus and Enterococcus genera are Gram positive bacteria and these results are consistent with previous studies (Altuner et al., 2012).

Bacterial fatty acid synthesis is controlled by enoyl-acyl carrier protein reductase (FabI) and this enzyme is significant in novel antibacterial agent research (Payne et al., 2001). Oleic, palmitic ( $n$-hexadecanoic acid) and linoleic (9,12-octadecadienoic acid (Z,Z)-) acids are known to inhibit FabI activity. Therefore, these unsaturated fatty acids have antibacterial potential (Zheng et al., 2005). According to GC-MS result, F. hirsuta ethanol extract include high amount of these molecules and their antibacterial potential can be related to these fatty acids.

Mesitylene (benzene,1,3,5-trimethyl-) is used in synthesis of new benzofuran compounds and it was previously proved that these compounds have antimicrobial activity against E. coli, C. albicans and $S$. aureus (Kirilmis et al., 2008). Eudesmic acid (benzoic acid, 3,4,5-trimethoxy-) has also antimicrobial activity against C. albicans and S. aureus (Bisignano et al., 2000). Stearic acid (octadecanoic acid) is an unsaturated fatty acid and some stearic acid analogues has antibacterial activity against $S$. aureus, B. subtilis, P. aeruginosa and E. coli (Jubie et al., 2012). B. subtilis, P. aeruginosa, C. albicans and $S$. aureus growth were inhibited by $F$. hirsuta ethanol extract and the inhibitions of these micro -organisms were important as a reason of being 
Table II

Major chemical components of $F$. hirsut $a$ according to the GC-MS analysis

\begin{tabular}{|c|c|c|c|c|c|c|c|}
\hline No & $\begin{array}{l}\text { Reten- } \\
\text { tion time }\end{array}$ & Chemical structure ${ }^{a}$ & $\begin{array}{l}\text { Compound } \\
\text { name }\end{array}$ & Formula & $\begin{array}{l}\text { Molecular } \\
\text { Weight } \\
(\mathrm{g} / \mathrm{mol})\end{array}$ & $\begin{array}{l}\text { Area } \\
(\%)\end{array}$ & Known activityb \\
\hline 1 & 8.0 & & $\begin{array}{l}\text { Benzene, } \\
1,3,5- \\
\text { trimethyl- }\end{array}$ & $\mathrm{C}_{9} \mathrm{H}_{12}$ & 120 & 7.0 & - \\
\hline 2 & 17.4 & & $\begin{array}{l}2- \\
\text { Furancar- } \\
\text { boxaldehy } \\
\text { de, 5- } \\
\text { (hydroxym } \\
\text { ethyl)- }\end{array}$ & $\mathrm{C}_{6} \mathrm{H}_{6} \mathrm{O}_{3}$ & 126 & 1.5 & - \\
\hline 3 & 31.0 & & $\begin{array}{l}\text { Benzoic } \\
\text { acid, 3,4,5- } \\
\text { trimethoxy } \\
\text { - }\end{array}$ & $\mathrm{C}_{10} \mathrm{H}_{12} \mathrm{O}_{5}$ & 212 & 2.1 & - \\
\hline 4 & 32.0 & - & unknown & - & - & 2.8 & - \\
\hline 5 & 33.1 & - & unknown & - & - & 0.7 & - \\
\hline 6 & 40.7 & & $\begin{array}{l}n- \\
\text { Hexadeca- } \\
\text { noic acid }\end{array}$ & $\mathrm{C}_{16} \mathrm{H}_{32} \mathrm{O}_{2}$ & 256 & 9.6 & $\begin{array}{l}\text { 5-Alpha-reductase-inhibitor, } \\
\text { antialopecic, antiandrogenic, } \\
\text { antifibrinolytic, anti-oxidant, } \\
\text { FLavor FEMA, hypercholester- } \\
\text { olemic, lubricant, nematicide, } \\
\text { pesticide, propecic, soap }\end{array}$ \\
\hline 7 & 46.9 & & $\begin{array}{l}\text { 9,12- } \\
\text { Octadeca- } \\
\text { dienoic } \\
\text { acid }(Z, Z)-\end{array}$ & $\mathrm{C}_{18} \mathrm{H}_{32} \mathrm{O}_{2}$ & 280 & 6.5 & $\begin{array}{l}\text { 5-Alpha-reductase-inhibitor, } \\
\text { antiacne, antialopecic, antiana- } \\
\text { phylactic, antiandrogenic, anti- } \\
\text { arteriosclerotic, antiarthritic, } \\
\text { anticoronary, antieczemic, } \\
\text { antifibrinolytic, antigranular, } \\
\text { antihistaminic, antiinflammato- } \\
\text { ry, antileukotriene-D4, an- } \\
\text { timenorrhagic, antiMS, anti- } \\
\text { prostatitic, cancer-preventive, } \\
\text { carcinogenic, comedolytic, } \\
\text { hepatoprotective, hypocholes- } \\
\text { terolemic, immunomodulator, } \\
\text { insectifuge }\end{array}$ \\
\hline 8 & 47.2 & & Oleic Acid & $\mathrm{C}_{18} \mathrm{H}_{34} \mathrm{O}_{2}$ & 282 & 26.3 & $\begin{array}{l}\text { 5-Alpha-reductase-inhibitor, } \\
\text { allergenic, alpha-reductase- } \\
\text { inhibitor, anemiagenic, an- } \\
\text { tialopecic, antiandrogenic, } \\
\text { antiinflammatory, antileukotri- } \\
\text { ene-D4, cancer, preventive, } \\
\text { choleretic, dermatitigenic, FLa- } \\
\text { vor FEMA, hypocholesterolem- } \\
\text { ic, insectifuge, perfumer, } \\
\text { propecic }\end{array}$ \\
\hline
\end{tabular}




\section{Table II}

\section{Major chemical components of $F$. hirsuta according to the GC-MS analysis (Cont.)}

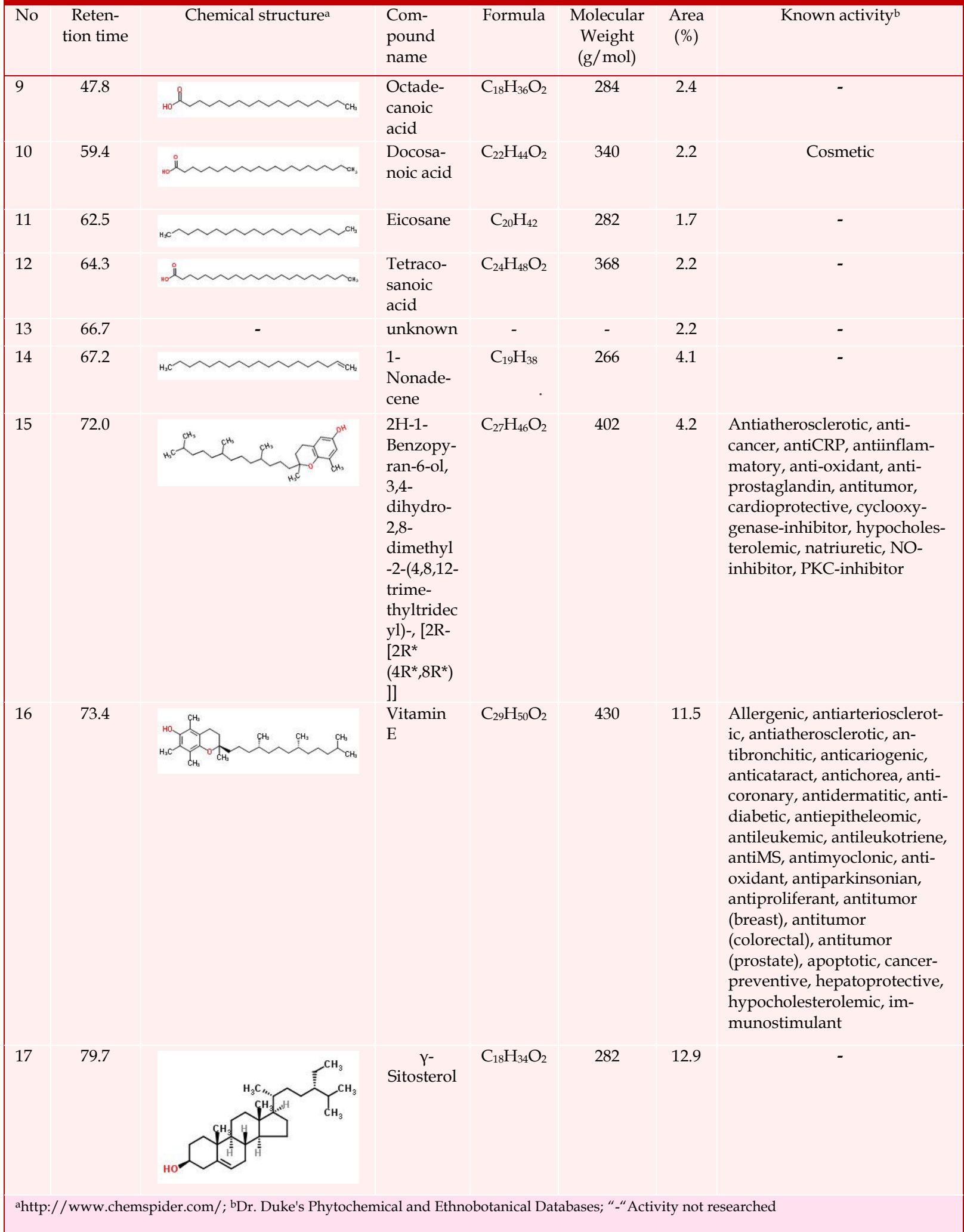


foodborne pathogens.

$\mathrm{Y}$-Sitosterol is also called as clionasterol (triterpenoid). Clionasterol was firstly isolated from Gracilaria edulis and it didn't show antimicrobial activity against $A$. niger and E. coli (McCabe-Sellers and Beattie, 2004). Many of the antimicrobial activities of $\gamma$-sitosterol have not been identified, so large scale micro-organism investigations such as MIC and disk diffusion methods are required.

F. hirsuta extract is observed to contain some fatty acids in relatively high amounts and they are important for foodborne pathogen treatment. Therefore, F. hirsuta extract might be used for industrial purposes in order to prevent contamination. On the other hand, the composition of F. hirsuta extract revealed that it contains relatively high amounts of some compounds, such as oleic acid and vitamin E, which are used to prepare some food supplements.

Moreover, some compounds were determined in the composition of F. hirsuta extract, which is not matching with the present libraries.

\section{Conclusion}

F. hirsuta ethanol extract has antimicrobial activity against large range of micro-organisms. These results are important because of being the first determination of the antimicrobial activity and biochemical composition of F. hirsuta.

\section{Conflict of Interest}

The authors declare that there is no conflict of interests regarding the publication of this paper.

\section{References}

Altuner EM, Akata I, Canli K. In vitro antimicrobial screening of Cerena unicolor (Bull.) Murrill (Polyporaceae Fr. Ex Corda). Fresen Environ Bull. 2012; 21: 3704-10.

Altuner EM, Canli K, Akata I. Antimicrobial screening of Calliergonella cuspidata, Dicranum polysetum and Hypnum cupressiforme. J Pure Appl Microbiol. 2013; 1: 539-45.

Becker RA, Chambers JM, Wilks AR. The New S Language. Wadsworth \& Brooks/Cole, 1992.

Bisignano G, Sanogo R, Marino A, Aquino R, Germano MP, De Pasquale R, Pizza C. Antimicrobial activity of Mitracarpus scaber extract and isolated constituents. Lett Appl Microbiol. 2000; 30: 105-08.

Canli K, Altuner EM, Akata I. Antimicrobial screening of Mnium stellare. Bangladesh J Pharmacol. 2015; 10: 321-25.

Canli K, Altuner EM, Akata I, Turkmen Y, Uzek U. In vitro antimicrobial screening of Lycoperdon lividum and determination of the ethanol extract composition by gas chromatography/mass spectrometry. Bangladesh J Pharmacol. 2016a; 11: 389-94.

Canli K, Akata I, Altuner EM. In vitro antimicrobial activity screening of Xylaria hypoxylon. Afr J Tradit Complement Altern Med. 2016b; 13: 42-46.

Canli K, Yetgin A, Akata I, Altuner EM. In vitro antimicrobial screening of Aquilaria agallocha roots. Afr J Tradit Complement Altern Med. 2016c; 13: 178-81.

Canli K, Yetgin A, Akata I, Altuner EM. Antimicrobial activity and chemical composition screening of Epilobium montanum root. Indian J Pharm Educ Res. 2017a; 51: 239-43.

Canli K, Yetgin A, Akata I, Altuner EM. Antimicrobial activity and chemical composition screening of Anacyclus pyrethrum root. Indian J Pharm Educ Res. 2017b; 51: 244-48.

Chambers JM, Hastie TJ. Statistical models in S, Wadsworth \& Brooks/Cole, 1992.

Daglia M. Polyphenols as antimicrobial agents. Curr Opin Biotechnol. 2011; 23: 174-81.

Delitheos A, Tiligada E, Yannitsaros A, Bazos I. Antiphage activity in extracts of plants growing in Greece. Phytomedicine 1997; 4: 117-24.

Hamzaoglu E, Aksoy A. Phytosociological studies on the halophytic communities of Central Anatolia. Ecology 2009; 18: $1-14$.

Jubie S, Ramesh PN, Dhanabal P, Kalirajan R, Muruganantham $\mathrm{N}$, Antony AS. Synthesis, antidepressant and antimicrobial activities of some novel stearic acid analogues. Eur J Med Chem. 2012; 54: 931-35.

Kirilmis C, Ahmedzade M, Servi S, Koca M, Kizirgil A, Kazaz C. Synthesis and antimicrobial activity of some novel derivatives of benzofuran: Part 2 . The synthesis and antimicrobial activity of some novel 1-(1-benzofuran-2-yl)-2-mesitylethanone derivatives. Eur J Med Chem. 2008; 43: 300-08.

McCabe-Sellers BJ, Beattie SE. Food safety: Emerging trends in foodborne illness surveillance and prevention. J Am Dietetic Assoc. 2004; 104: 1708-17.

Mead PS, Slutsker L, Dietz V, McCaig LF, Bresee JS, Shapiro C, Griffin PM, Tauxe, RV. Food-related illness and death in the United States. Emerg Infect Dis. 1999; 5: 607-25.

Payne DJ, Warren PV, Holmes DJ, Ji Y, Lonsdale JT. Bacterial fatty-acid biosynthesis: A genomic-driven target for antibacterial drug discovery. Drug Discov Today. 2001; 6: 537-44.

Team RC. R: A language and environment for statistical computing. Vienna, R foundation for statistical computing, 2016

United States Department of Agriculture Economic Research Services. Foodborne illness cost calculator. Washington, DC, USDA, 2010

Vural M, Duman H, Aytac Z, Adiguzel N. A new genus and three new species from Central Anatolia, Turkey. Turk J Bot. 2014; 36: 427-33.

Yousif F, Hifnawy MS, Soliman G, Boulos L, Labib T, 
Mahmoud S, Ramzy F, Yousif M, Hassan I, Mahmoud K, ElHallouty SM, El-Gendy M, Gohar L, El-Manawaty M, Fayyad W, El-Menshawi BS. Large-scale in vitro screening of Egyptian native and cultivated plants for schistosomicidal activity. Pharm Biol. 2007; 45: 501-10.
Zheng CJ, Yoo J, Lee T, Cho H, Kim Y, Kim W. Fatty acid synthesis is a target for antibacterial activity of unsaturated fatty acids. FEBS Lett. 2005; 579: 5157-62.

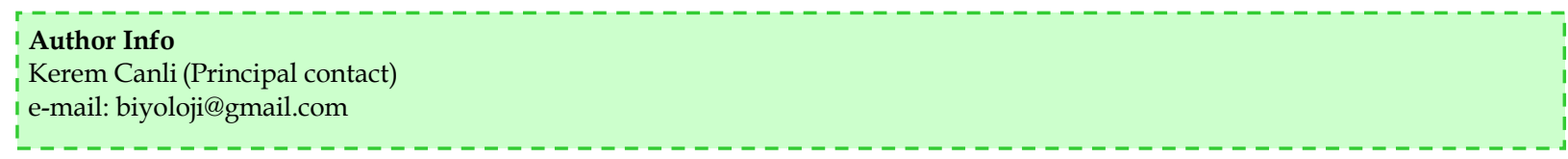

